Agi T. Melton MD, Joseph F. Antognini MD, Gerald A. Gronert MD

\title{
Prolonged duration of succinylcholine in patients receiving anticonvulsants: evidence for mild up- regulation of acetylcholine receptors?
}

Succinylcholine (SCh) normally causes a small increase in serum potassium concentration, but certain conditions may predispose to severe hyperkalaemia. This is due to "up-regulation" of skeletal muscle acetylcholine receptors $(A C h R)$, which also results in resistance to non-depolarizing muscle relaxants (NDMR). Anticonvulsant therapy causes NDMR resistance because of sub-clinical blockade, and diminished release, of acetylcholine. We studied nine patients chronically receiving anticonvulsants (phenytoin and/or carbamazepine) and nine control patients. Anaesthesia was induced typically with thiopenlone or propofol; isoflurane and $\mathrm{N}_{2} \mathrm{O}$ were used for maintenance. The ulnar nerve was supramaximally stimulated and mechanical twitch height was measured with a force transducer at the adductor pollicis, before and after SCh $1 \mathrm{mg} \cdot \mathrm{kg}^{-1}$, until return to baseline height. Plasma potassium concentration was measured before and at three, five, and ten minutes following SCh. Mean maximum potassium rise was $0.2 \mathrm{mEq} \cdot \mathrm{L}^{-l}$ in each group. The time for return to baseline twitch height was $14.3 \pm 2.3 \mathrm{~min}$ (mean $\pm S D$ ) in the anticonvulsant group

Key words

IONS: potassium;

NEUROMUSCULAR RELAXANTS: succinylcholine;

PHARMACOLOGY: anticonvulsants, phenytoin,

carbamazepine;

RECEPTORS: acetylcholine.

From the Department of Anesthesiology, University of

California, Davis.

Address correspondence to: Dr. Joseph F. Antognini,

Department of Anesthesiology, TB-170, University of

California, Davis, Davis, California, USA 95616.

Accepted for publication 17th June, 1993. and $10.0 \pm 1.6 \mathrm{~min}$ in the control group, $P=0.001$. The recovery index (time for $25 \%$ to $75 \%$ recovery) was $2.6 \pm 0.9$ min in the anticonvulsant group and $1.4 \pm 0.3 \mathrm{~min}$ in the control group, $P<0.01$. The normal potassium response coupled with prolonged duration suggests a hypersensitivity to $S C h$ that is consistent with an anticonvulsant-induced mild upregulation of $A C h R$.

Normalement, la succinylcholine ne provoque qu'une légère augmentation du potassium sérique, mais certaines conditions peuvent favoriser une hyperkaliémie grave. Ceci est dû à la régulation "à la hausse " des récepteurs acétylcholinergiques des muscles squelettiques ( $A C h R$ ), qui produit aussi une résistance aux myo-relaxants non dépolarisants (MRND). Par un bloquage infraclinique, la thérapie anticonvulsivante produit une résistance aux MRND et une diminution de la libération d'acétylcholine. Nous avons étudié neuf patients sous thérapie anticonvulsivante (du phénytoin ou de la carbamazépine) et les avons comparés à neuf contrôles. L'anesthésie a été induite avec du thiopentone ou du propofol et maintenue à l'isoflurane et au $\mathrm{N}_{2} \mathrm{O}$. Un stimulus supramaximal a été appliqué au nerf cubital et la force du twitch mesurée avec un transducteur à l'adducteur court du pouce, avant et après $S C h \mathrm{l} \mathrm{mg} \cdot \mathrm{kg}^{-1}$, jusqu'au retour à la ligne de base. La kaliémie a été mesurée avant, à trois, cinq, et dix minutes après SCh. L'augmentation moyenne maximale de potassium a été de $0,2 \mathrm{mEq} \cdot \mathrm{L}^{-1}$ dans chaque groupe. La durée de retour à la ligne de base a été de 14,3 $\pm 2,3 \mathrm{~min}$ (moyenne $\pm S D$ ) dans le groupe anticonvulsivant et 10,0 $\pm 1,6$ dans le groupe contrôle, $P=0,001$. Lindex de récupération (temps de récupération à $25 \%$ à $75 \%$ ) $a$ été de 2,6 \pm 0.9 min dans le groupe anticonvulsivant et de $1,4 \pm 0,3$ min dans le groupe contrôle, $P<0,01$. La normalité de la réponse kaliémique associée à une durée prolongée suggère une hypersensibilité à la SCh consistante avec une légère régulation "à la hausse " induite par la thérapie anticonvulsivante. 
Succinylcholine ( $\mathrm{SCh}$ ) is a depolarizing muscle relaxant which normally causes a $0.2-0.5 \mathrm{mEq} \cdot \mathrm{L}^{-1}$ increase in serum potassium concentration. ${ }^{1,2}$ Succinylcholine use in certain clinical conditions (e.g., burns, denervation, muscle damage, etc.), may lead to a dramatic and sometimes fatal increase in serum potassium. ${ }^{3}$ This phenomenon is secondary to the development of new immature acetylcholine receptors (AChR) in skeletal muscle, and it also leads to resistance to non-depolarizing muscle relaxants (NDMR). ${ }^{4}$ Anticonvulsants, such as phenytoin and carbamazepine, decrease acetylcholine release and produce a mild acetylcholine blockade at the neuromuscular junction (NMJ). ${ }^{5,6}$ While there is no evidence of clinical weakness, anticonvulsants do result in NDMR resistance, ${ }^{7-10}$ and the mechanism has been related to increased AChR." To examine this issue, we analyzed potassium changes and twitch responses to $S C h$ in patients receiving chronic anticonvulsant therapy.

\section{Methods}

With approval by the Human Subjects Review Committee, informed consent was obtained from nine patients taking phenytoin and/or carbamazepine for at least one month and nine control patients. Patients with disorders associated with myopathies or up-regulation, e.g., neuromuscular diseases and/or motor deficits, burns, and recent muscle trauma were excluded. Patients in the anticonvulsant group had therapeutic drug levels except for one patient whose phenytoin level was $8 \mathrm{mg} \cdot \mathrm{L}^{-1}$ (therapeutic range $10-20 \mathrm{mg} \cdot \mathrm{L}^{-1}$.

A radial arterial catheter was placed in each patient prior to induction. Anaesthetic management was left to the attending anaesthetist. Patients were given fentanyl $1-4 \mu \mathrm{g} \cdot \mathrm{kg}^{-1}$ (five control, seven anticonvulsant), midazolam 0.01-0.04 $\mu \mathrm{g} \cdot \mathrm{kg}^{-1}$ (four control, two anticonvulsant), lidocaine $1-1.4 \mathrm{mg} \cdot \mathrm{kg}^{-1}$ (two control, two anticonvulsant) followed by an induction dose of thiopentone $3.7-6.5 \mathrm{mg} \cdot \mathrm{kg}^{-1}$ (six control, seven anticonvulsant), propofol $2 \mathrm{mg} \cdot \mathrm{kg}^{-1}$ (one control, one anticonvulsant), or etomidate $0.34-0.46 \mathrm{mg} \cdot \mathrm{kg}^{-1}$ (two control, zero anticonvulsant) followed by $\mathrm{SCh} 1 \mathrm{mg} \cdot \mathrm{kg}^{-1}$. Nitrous oxide and isoflurane (approximately 1\%) were used for maintenance. Arterial blood samples were taken prior to and three, five, and ten minutes after SCh administration. These were analyzed for potassium (ion-specific electrode, accuracy $\pm 0.1 \mathrm{mEq} \cdot \mathrm{L}^{-1}$ ) and $\mathrm{PaCO}_{2}$ (Nova Stat Profile 5, Nova Medical, Tewksbury, MA).

Prior to induction, the hand was stabilized and the thumb fixed to an FT-10 transducer, with a resting tension of approximately $200 \mathrm{~g}$. The mechanical twitch of the adductor pollicis muscle was recorded (Model MT8500 , Astro-Med, W. Warwick, RI). Skin electrodes were placed over the ulnar nerve at the wrist, and following
TABLE Potassium concentrations $\left(\mathrm{mEq} \cdot \mathrm{L}^{-1}\right)$ before and after succinylcholine injection

\begin{tabular}{lllll}
\hline & Baseline & $3 \min$ & $5 \min$ & $10 \min$ \\
\hline Control & $3.8 \pm 0.4$ & $4.0 \pm 0.5$ & $4.0 \pm 0.5$ & $4.0 \pm 0.5$ \\
Anticonvulsant & $4.0 \pm 0.2$ & $4.0 \pm 0.2$ & $4.1 \pm 0.4$ & $4.2 \pm 0.4$ \\
\hline
\end{tabular}

ANOVA: no differences

induction, supramaximal stimulation (Digistim, II, Neurotechnology, Houston, TX) at $1 \mathrm{~Hz}$ was performed before and after $\mathrm{SCh}$, until twitch height achieved pre-SCh levels. Duration of twitch depression was the time in minutes from $\mathrm{SCh}$ injection until twitch height returned to pre-SCh levels. Recovery index (time for recovery from $25 \%$ to $75 \%$ of twitch height) and time to $50 \%$ recovery were also determined.

Data are expressed as mean $\pm \mathrm{SD}$. Changes in serum potassium and $\mathrm{PaCO}_{2}$ were evaluated using analysis of variance (ANOVA), and Student's $t$ test was used to evaluate differences between the groups as regards twitch depression durations and recovery index; significance was attained when $P<0.05$.

\section{Resuits}

The anticonvulsant group included five men and four women, aged $41 \pm 11 \mathrm{yr}$ and weight $79 \pm 16 \mathrm{~kg}$. Four men and five women, aged $40 \pm 12 \mathrm{yr}$ and weight 76 $\pm 17 \mathrm{~kg}$ formed the control group.

The increase in potassium concentration after $\mathrm{SCh}$ was not different between the anticonvulsant group and the control group (Table). Potassium data from one control patient were discarded due to clotting of the baseline sample. Twitch recovery time was unobtainable in one patient in the anticonvulsant group for technical reasons. Profound (98-100\%) twitch depression occurred in all patients. Recovery of baseline (pre-SCh) twitch height following SCh administration was longer in the anticonvulsant group (14.3 $\pm 2.3 \mathrm{~min}, n=8)$ than in the control group (10.0 $\pm 1.6 \mathrm{~min}, n=9), P=0.001$. Time for recovery to $50 \%$ twitch height was $11.4 \pm 0.7 \mathrm{~min}$ in the anticonvulsant group and $8.4 \pm 1.7 \mathrm{~min}$ in the control group, $P<0.01$. Corresponding recovery indexes were $2.6 \pm 0.9 \mathrm{~min}$ and $1.4 \pm 0.3 \mathrm{~min}, P<0.01$. The $\mathrm{PaCO}_{2}$ was $43 \pm 4 \mathrm{mmHg}$ prior to induction of anaesthesia in the anticonvulsant group, and $43 \pm 6 \mathrm{mmHg}$ in controls. These did not change at three, five and ten minutes in either group.

\section{Discussion}

Acute effects of anticonvulsant therapy include a mild neuromuscular blockade which potentiates d-tubocurarine and other NDMR. ${ }^{5,6}$ This mild neuromuscular blockade is apparently not manifested clinically as 


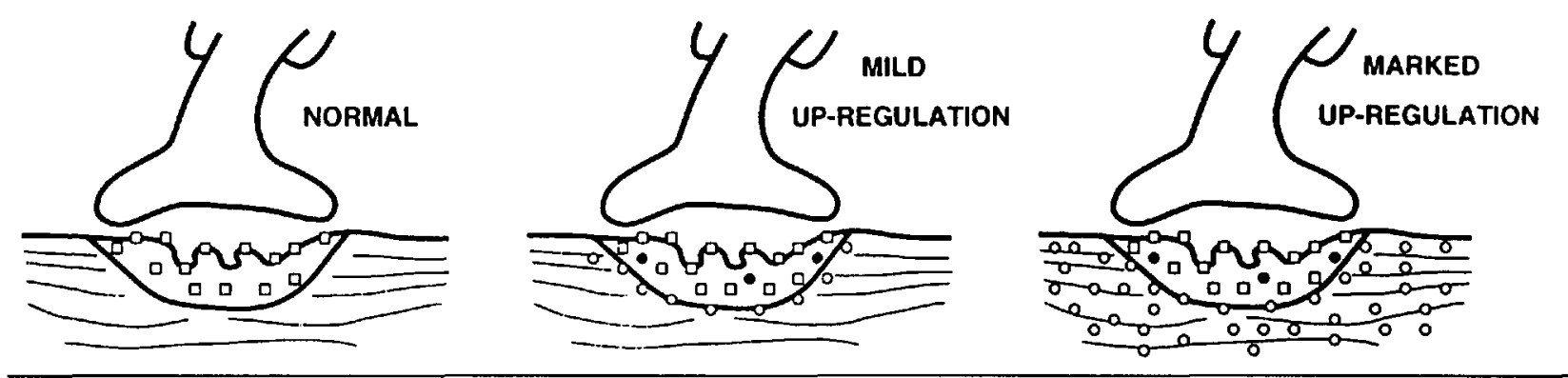

FIGURE Schematic of a normal neuromuscular junction, and changes associated with mild and marked up-regulation. $\square$ Mature receptor; OImmature receptor; OUnconfirmed immature receptor. See text for details.

weakness due to the large amount of $\mathrm{AChR}$ available in reserve-also known as the margin of safety of neuromuscular transmission. ${ }^{4}$ The neuromuscular blocking effect of anticonvulsants is due to a modest blockade of acetylcholine effects and a decrease in acetylcholine release, ${ }^{5,6}$ which is thought to result in proliferation of AChR, leading to up-regulation. Thus, chronic effects of anticonvulsants, seen after about two weeks, include resistance to competitive antagonists, e.g., NDMRs. ${ }^{4,11}$ For example, studies in rats have shown a modest elevation of AChR number and resistance to metocurine following a two-week course of phenytoin, although part of this resistance is possibly secondary to increased protein binding. ${ }^{.1}$ The degree of resistance appears comparable to that produced by an upper motor neuron lesion (UMNL), ${ }^{12}$ thermal trauma, ${ }^{13}$ or disuse atrophy, ${ }^{14}$ although specific direct comparisons have not been made. To achieve 50\% twitch depression, an UMNL patient requires muscle relaxant blood levels $2-3 \times$ normal; ${ }^{12}$ for thermal trauma, $2 \times$ normal; ${ }^{13}$ for disuse atrophy, at least $2 \times$ normal; ${ }^{14}$ and for anticonvulsants, $1.7 \times$ normal. ${ }^{15}$ Thus, for pharmacodynamic, and not pharmacokinetic reasons, a similar increase in blood level and dose of NDMR is required in all of these conditions.

Up-regulation resulting from UMNL and thermal trauma is extensive as evidenced by potentially lethal hyperkalaemia in response to $\mathrm{SCh},{ }^{4}$ whereas we believe upregulation in response to anticonvulsants is mild. This is based on our data and is possibly explained by the weak junctional blocking effects of anticonvulsants. ${ }^{4}$ This speculative difference between mild and marked upregulation is outlined in the Figure. Mild up-regulation is thought to occur during anticonvulsant therapy, and because the effect occurs at the endplate, new immature receptors appear perijunctionally; the presence of new receptors actually within the NMJ is unconfirmed. These new AChRs increase the margin of safety, resulting in NDMR resistance. However, there are insufficient numbers to result in hyperkalaemia. With marked upregulation, e.g., following thermal trauma, new receptors spread throughout the muscle membrane. Those in the perijunctional region cause NDMR resistance, while the overall numerical increase results in hyperkalaemia after $\mathrm{SCh}$. Thus, in theory, up-regulation in response to anticonvulsants, resulting in development of new receptors only in the junctional and perijunctional areas, could reconcile the similar degree of NDMR resistance compared with burns and UMNL, and the lack of hyperkalaemic response to SCh. Our data are consistent with those of Platt et al., who found a normal potassium efflux following $\mathrm{SCh}$ in patients receiving anticonvulsants. ${ }^{16}$ Platt et al. also speculate that mild up-regulation of $\mathrm{AChR}$ could account for these data. ${ }^{16}$

Studies in rats indirectly support the distinction between mild and marked up-regulation. The proportional increase in perijunctional AChR after thermal trauma ${ }^{17}$ is similar to the increase in perijunctional $A C h R$ during anticonvulsant therapy: " Since hyperkalaemia does not occur with the latter, these data suggest that the number of receptors perijunctionally is similar for both conditions (e.g., resistance) and that total numbers are greatly increased only for thermal trauma.

Hypersensitivity to SCh and NDMR resistance following up-regulation of $A C h R$ is also due, in part, to the binding characteristics of the immature AChR. ${ }^{4}$ These new receptors are more sensitive to agonists, e.g., $\mathrm{SCh}$, and one-tenth to one-hundredth of normal doses can depolarize the end plate. ${ }^{4}$ Binding of antagonists, e.g., NDMR, is decreased, resulting in resistance. Our data suggest increased sensitivity to $\mathrm{SCh}$, in that the anticonvulsant group had a slight prolongation of action. This prolongation is not likely due to alteration of pseudocholinesterase activity, since carbamazepine and phenytoin induce, not inhibit, pseudocholinesterase. ${ }^{18}$ Likewise, the varied induction agents would not be expected to have affected our results, since these agents, in the doses used, have no effect on $\mathrm{SCh},{ }^{19}$ and were fairly evenly distributed between the control and anticonvulsant groups. Last, we did not examine NDMR pharmacodynamics in our patients; however, that anticonvulsants 
consistently cause NDMR resistance is well established. . $^{70}$

Other conditions which might have similar degrees of mild up-regulation include cerebral palsy ${ }^{20,21}$ and disuse atrophy of a single limb. ${ }^{14,22}$ In these cases, NDMR resistance occurs in the absence of hyperkalaemia. ${ }^{4,20-22}$

The slight prolongation of SCh action in patients taking anticonvulsants has few clinical implications. One, however, is the situation of an unanticipated difficult airway, where return of spontaneous breathing facilitates airway management.

In summary, mild AChR up-regulation in response to chronic anticonvulsant therapy is a speculative and reasonable pharmacodynamic explanation for the lack of hyperkalaemia in conjunction with prolonged twitch depression following $\mathrm{SCh}$ in humans taking anticonvulsants.

\section{References}

1 Valentin N, Skousted P, Danielsen B. Plasma potassium following suxamethonium and electroconvulsive therapy. Acta Anaesthesiol Scand 1973; 17: 197-202.

2 Mazze RI, Escue HM, Houston JB. Hyperkalaemia and cardiovascular collapse following administration of succinylcholine to the traumatized patient. Anesthesiology 1969; 31: 540-7.

3 Gronert GA, Theye RA. Pathophysiology of hyperkalemia induced by succinylcholine. Anesthesiology 1975; 43: 89-99.

4 Martyn JAJ, White DA, Gronert GA, Jaffe RS, Ward JM. Up-and-down regulation of skeletal muscle acetylcholine receptors. Effects on neuromuscular blockers. Anesthesiology 1992; 76: 822-43.

5 Norris FH Jr, Colella J, McFarlin D. Effect of diphenylhydantoin on neuromuscular synapse. Neurology 1964; 14: 869-76.

6 Gray HStJ, Slater RM, Pllard BJ. The effect of acutely administered phenytoin on vecuronium-induced neuromuscular blockade. Anaesthesia 1989; 44: 379-81.

7 Tempelhoff $R$, Modica PA, Jellish WS, Spitznagel EL. Resistance to atracurium-induced neuromuscular blockade in patients with intractable seizure disorders treated with anticonvulsants. Anesth Analg 1990; 71: 665-9.

8 Roth S, Ebrahim ZY. Resistance to pancuronium in patients receiving carbamazepine. Anesthesiology 1987; 66 : 691-3.

9 Ornstein E, Matteo RS, Schwartz AE, Silverberg $P A$, Young $W L$, Diaz $J$. The effect of phenytoin on the magnitude and duration of neuromuscular block following atracurium or vecuronium. Anesthesiology 1987; 67: 191-6.

10 Ornstein E, Matteo RS, Young WL, Diaz J. Resistance to metocurine-induced neuromuscular blockade in patients receiving phenytoin. Anesthesiology 1985; 63: 294-8.

11 Kim CS, Arnold FJ, Itani MS, Martyn JAJ. Decreased sensitivity to metocurine during long-term phenytoin ther- apy may be attributable to protein binding and acetylcholine receptor changes. Anesthesiology 1992; 77: 500-6.

12 Shayevitz IR, Matteo RS. Decreased sensitivity to metocurine in patients with upper motoneuron disease. Anesth Analg 1985; 64: 767-72.

13 Martyn JAJ, Goudsouzian NG, Matteo RS, Liu LMP, Szyfelbein SK, Kaplan RF. Metocurine requirements and plasma concentrations in burned paediatric patients. $\mathrm{Br} \mathrm{J}$ Anaesth 1983; 55: 263-7.

14 Gronert GA, Matteo RS, Perkins S. Canine gastrocnemius disuse atrophy: resistance to paralysis by dimethyl tubocurarine. J Appl Physiol 1984; 57: 1502-6.

15 Ornstein E, Matteo RS, Young WL, Diaz J. Resistance to metocurine-induced neuromuscular blockade in patients receiving phenytoin. Anesthesiology 1985; 63: 294-8.

16 Platt $P R$. Thackray NM. Phenytoin-induced resistance to vecuronium. Anaesth Intensive Care 1993; 21: 185-91.

17 Kim C, Fuke N, Martyn JAJ. Burn injury to rat increases nicotine acetylcholine receptors in the diaphragm. Anesthesiology 1988; 68: 401-6.

18 Puche E, Garcia Morillas M, Garcia de la Serrana H, Mota $C$. Probable pseudocholinesterase induction by valproic acid, carbamazepine and phenytoin leading to increased serum aspirin-esterase activity in epileptics. Int $\mathrm{J}$ Clin Pharm Res 1989; 9: 309-11.

19 Bevan DR, Bevan JC, Donati F. Muscle Relaxants in Clinical Anesthesia. Chicago: Year Book Medical Publishers Inc., 1988; 389-413.

20 Moorthy SS, Krishna G, Dierdorf SF. Resistance to vecuronium in patients with cerebral palsy. Anesth Analg 1991; 73: 275-7.

21 Dierdorf SF, McNiece $W L$, Rao CC, et al. Effect of succinylcholine on plasma potassium in children with cerebral palsy. Anesthesiology 1985; 62: 88-90.

22 Fung $D L$, White DA, Jones BR, Gronert GA. The onset of disuse-related potassium efflux to succinylcholine. Anesthesiology 1991; 75: 650-3. 